\title{
Distribution of vascular plants in a subalpine-nival gradient of Central Himalaya: current patterns and predictions for future warming climate
}

\author{
Laxmi Raj Joshi ${ }^{{ }^{*}}$, Suresh Kumar Ghimire ${ }^{1^{*}}$, Jan Salick² and Katie M. Konchar ${ }^{2}$ \\ ${ }^{1}$ Central Department of Botany, Tribhuvan University, Kirtipur, Kathmandu, Nepal; ${ }^{2}$ Missouri Botanical Garden, St. Louis, \\ Missouri, USA
}

\begin{abstract}
Following the standard method of Global Research Initiative in Alpine Environments (GLORIA), we performed a systematic investigation of vascular plant species distribution along a subalpine to nival gradient in the Central Himalaya. Our study aims to identify the richness and distribution patterns of vascular plant species and biogeographic groups under current climatic conditions and make predictions for their distribution under warmer conditions anticipated by the Intergovernmental Panel on Climate Change (IPCC). Species richness decreased along an increasing elevation gradient. Aspect also influenced richness levels along the study gradient. Biogeographically, a majority of taxa were Himalayan endemics, followed by species with pan-Himalayan distribution. A complete turnover of indicator species along the elevation gradient was observed due to distinct phytoclimates. Twenty three percent of the plant species recorded in the present study showed a narrow elevation amplitude (<1250 masl) and are projected to be most sensitive to rising global surface temperatures. Taxa with restricted geographical distribution and narrow elevation amplitude must adapt through range shift to compensate for expected future increases in temperature. However, limited habitat availability may hinder the ability of high alpine species to migrate upward in elevation.
\end{abstract}

Key-words: Species distribution, life forms, chorotypes, climate change, range shift.

\section{Introduction}

The alpine-nival life zone exclusively encompasses vegetation above tree line and below permanent snow line where life is constrained by physical components of the environment, mainly low temperature and hence low energy, high solar radiation, strong wind, and short growth period (Körner 2003; Nagy and Grabherr 2009). Despite environmental stresses, most of the alpine-nival

*Correspondence, e-mail: laxmi_raj100@yahoo.com; sk.ghimire@cdbtu.edu.np; Tel: +977 14331322. regions are biodiversity hotspots inhabited by a substantial number of rare and endemic taxa (Salick and Byg 2007; Salick et al. 2014) important from economic, ecological and evolutionary perspectives in addition to their conservation significance.

Gradients in temperature, water availability, light and soil nutrients all vary with elevation and are important to shaping plant distribution (Körner 2003; Jonas et al. 2008). Decreasing temperature and precipitation with increasing elevation results in the success of species with life forms better adapted to cold and dryness (Klîmes 2003; Vittoz et al. 2010; Grau et al. 
2012). Besides these environmental variables, topographic variables, aspect and slope, influence the amount of radiation received in a particular mountain area and considerably affect plant species distribution and diversity at the local scale (O’Brien 1998; McCune 2007).

The recurrence of fluctuating climatic conditions during the Quaternary has greatly affected the migration and adaptation of flora in mountain regions and subsequently influenced the distribution of taxa and the speciation rate, thereby influencing the extent of endemism (Mani 1978; Tribsch and Schönswetter 2003; Yoshida 2006). The Himalaya and neighboring mountain ranges are considered one of the most active regions in the world for the speciation of seed plants during the Quaternary (Yoshida 2006). As a result, this region supports high flowering plant diversity and endemism. One current estimate suggests that out of an estimated 10,000 species of plants in the Himalaya, about 3,160 are endemic (Conservation International 2012) and endemic species richness in the Himalaya is greater than reported in the European alpine environment (Salick et al. 2014).

Endemic species richness in the Himalaya is expected to be especially high at high elevation zones, particularly between the subalpine and upper alpine belt (Shrestha and Joshi 1996; Vetaas and Grytnes 2002; Ghimire 2005). In contrast, the total species richness along this gradient declines monotonically with the rise in elevation (Lomolino 2001; Körner 2003; Vittoz et al. 2010). Most of the endemic species so far reported from Nepal have a very narrow range size and show high habitat specificity (Shrestha and Joshi 1996; Ghimire 2005; Rajbhandari and Adhikari 2009).

Most global environmental issues including climate change are expected to have greater impact on the biodiversity at higher elevations. The study of current taxa distribution patterns along an elevation gradient provides baseline knowledge for predicting future distributions and for evaluating the relative impacts of environemntal changes over time. It is already an established fact that high altitude regions favor species with narrow ranges of distribution. Studying the impacts of climate change on such species has wider implications for species and habitat conservation strategies in the
Himalaya. Long-term ecological monitoring on high altitude taxa will serve this need.

Following the method of the Global Observation Research Initiative in Alpine Environments (GLORIA), this study aims to assess species distribution patterns under current climatic conditions along a subalpine-nival gradient in Central Nepal and make predictions for vascular plant distribution under warmer climatic conditions anticipated by the Intergovernmental Panel on Climate Change (IPCC). Specifically, we assess the biogeographic (chorotypic) and elevation patterns of distribution of vascular plant species on mountain summits at various elevations, identify indicator species along ecological zones (ecotones) represented by mountain summits, and evaluate future distribution of vascular plant species in response to their exposure to more warmer climatic conditions. The globally standardized GLORIA protocol (Grabherr et al. 2001; Pauli et al. 2004) has been utilized in high altitude regions around the world. Completing long-term ecological monitoring in Central Nepal will link the observed impacts of climate change on vascular plant species unique to this region to wider Himalayan and global datasets and provide baseline information useful in interpreting the impacts of anticipated climatic change on species distribution patterns.

\section{Materials and Methods}

\section{STUDY AREA}

The study area is located in north-eastern part of Nyeshang valley in Manang district within Annapurna Conservation Area (ACA), Nepal (Figure 1, Table 1). Manang district lies in the partial rain shadow zone surrounded by Annapurna (>7500 masl), Lamjung (6932 masl) and Manaslu (8163 masl) mountain series. Thus the area is characterized by low annual precipitation $(<400 \mathrm{~mm})$ compared to the other mountainous areas of Nepal. Analysis of 30 years of temperature and precipitation data at two nearby meteorological stations, Chame and Jomsom stations, revealed the annual mean maximum temperature of $16.73^{\circ} \mathrm{C}$ and $17.61^{\circ} \mathrm{C}$, annual mean 

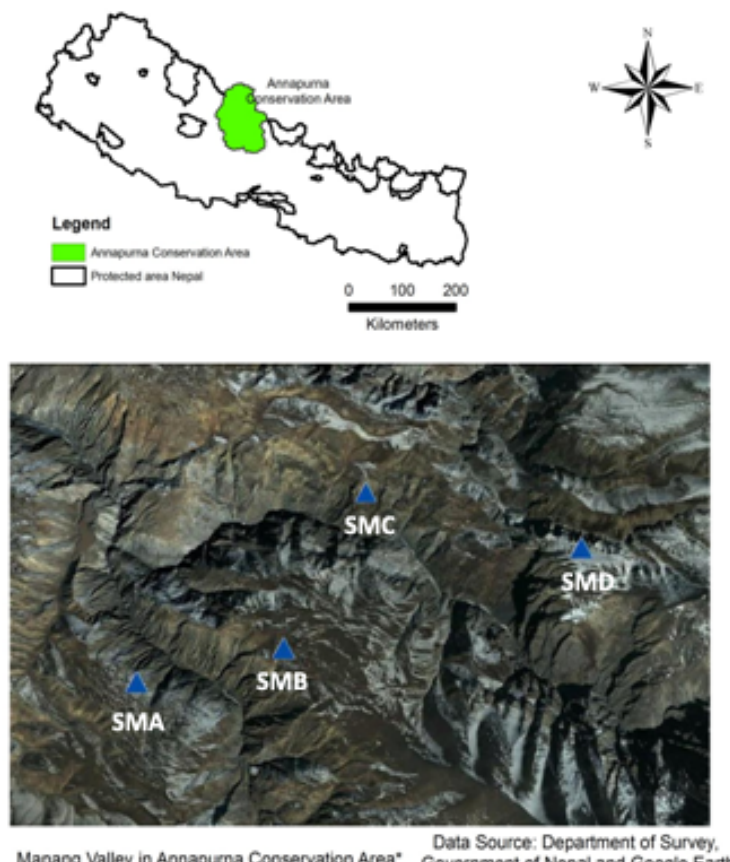

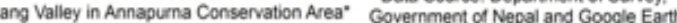
"Blue traingles indicate studied summits

Figure 1. Study sites in Nyeshang valley, Manang include 4 summits: SMA = subalpine-lower alpine $(4150 \mathrm{~m})$; SMB = lower alpine-middle alpine (4575 m), SMC = middle alpineupper alpine (4835 m), SMD = upper alpine-subnival (5005 m).

minimum temperature of $4.8^{\circ} \mathrm{C}$ and $5.48^{\circ} \mathrm{C}$, and annual mean precipitation of $948.73 \mathrm{~mm}$ and $269.37 \mathrm{~mm}$, respectively.

\section{VEGETATION SAMPLING AND DATA COLLECTION}

We followed standardized methods for GLORIA (Grabherr et al. 2001; Pauli et al. 2004; Figure 2) to establish long-term research plots in Nyeshang valley, Manang. Permanent plots are also part of a larger Himalayan climate change and biodiversity study (Salick et al. 2014).

Four summits were selected along an elevation gradient between tree line and permanent snowline representing four ecotones: subalpine-lower alpine, lower alpine-middle alpine, middle alpine-upper alpine, and upper alpine-subnival (Figure 1, Table 1). In each summit, vegetation sampling was completed at three spatial scales: (i) $1 \mathrm{~m} \mathrm{x} 1 \mathrm{~m}$ quadrats, (ii) quadrat-clusters (consisting of four $1 \mathrm{~m} \times 1 \mathrm{~m}$ quadrats), and (iii) large summit area sections (SAS) (Figure 2). Each summit was divided into eight SAS: (i) four upper SAS representing four cardinal directions (N, S, E and W) from the highest summit point (HSP, top of the summit) down $5 \mathrm{~m}$ in vertical elevation, and (ii) four lower SAS representing four cardinal directions from the $5 \mathrm{~m}$ corner point of upper SAS further down $5 \mathrm{~m}$ in vertical elevation. At each cardinal direction and $5 \mathrm{~m}$ vertical elevation from the HSP, one $3 \mathrm{~m} \times 3 \mathrm{~m}$ grid (quadrat-cluster) was positioned (thus totaling four such grids at four cardinal directions per summit). Each grid was divided into nine $1 \mathrm{~m} \mathrm{x} 1 \mathrm{~m}$ quadrats, out of which four quadrats at each corner of the grid were selected for vegetation sampling. Altogether, sixteen $1 \mathrm{~m}$ x $1 \mathrm{~m}$ quadrats were sampled in each summit.

Presence of species was recorded in each SAS. Combining the species presence from all eight SAS gave total summit flora. In each of the sixteen $1 \mathrm{~m} \mathrm{x} 1 \mathrm{~m}$ quadrats, species cover (\%) of each vascular plant, and

Table 1. Geographical location and dominant plant species of four different summits studied.

\begin{tabular}{|c|c|c|c|c|}
\hline Summit & Vegetation zone & Latitude & Longitude & Major vegetation \\
\hline $\begin{array}{l}\text { SMA } \\
(4150 \mathrm{~m} \text { asl })\end{array}$ & $\begin{array}{l}\text { Subalpine - lower alpine } \\
\text { ecotone }\end{array}$ & $28^{\circ} 67.418^{\prime}$ & $84^{\circ} 04.060^{\prime}$ & $\begin{array}{l}\text { Cicerbita macrorhiza var. saxatilis, Galium } \\
\text { megacyttarion, Juniperus squamata, } \\
\text { Polygonatum cirrhifolium }\end{array}$ \\
\hline $\begin{array}{l}\text { SMB } \\
(4575 \mathrm{~m} \text { asl })\end{array}$ & $\begin{array}{l}\text { Lower alpine - middle } \\
\text { alpine ecotone }\end{array}$ & $28^{\circ} 67.631^{\prime}$ & $84^{\circ} 05.206^{\prime}$ & $\begin{array}{l}\text { Anaphalis royleana, Lonicera obovata, , } \\
\text { Potentilla argyrophylla var. atrosanguinea, } \\
\text { Sibbaldia parviflora, Viola biflora }\end{array}$ \\
\hline $\begin{array}{l}\text { SMC } \\
(4835 \mathrm{~m} \text { asl })\end{array}$ & $\begin{array}{l}\text { Middle alpine - upper } \\
\text { alpine ecotone }\end{array}$ & $28^{\circ} 68.767^{\prime}$ & $84^{\circ} 05.807^{\prime}$ & $\begin{array}{l}\text { Bistorta macrophylla, Cortia depressa, } \\
\text { Cremanthodium nepalense, Gentiana algida } \\
\text { var. przewalskii, Kobresia pygmaea, } \\
\text { Lomatogonium himalayense, Nardostachys } \\
\text { grandiflora, Rhododendron anthopogon, }\end{array}$ \\
\hline $\begin{array}{l}\text { SMD } \\
(5005 \mathrm{~m} \text { asl })\end{array}$ & $\begin{array}{l}\text { Upper alpine-subnival } \\
\text { ecotone }\end{array}$ & $28^{\circ} 68.296^{\prime}$ & $84^{\circ} 07.482^{\prime}$ & $\begin{array}{l}\text { Eriophyton wallichii, Potentilla fruticosa, } \\
\text { Saussurea leontodontoides, Saxifraga } \\
\text { andersonii }\end{array}$ \\
\hline
\end{tabular}




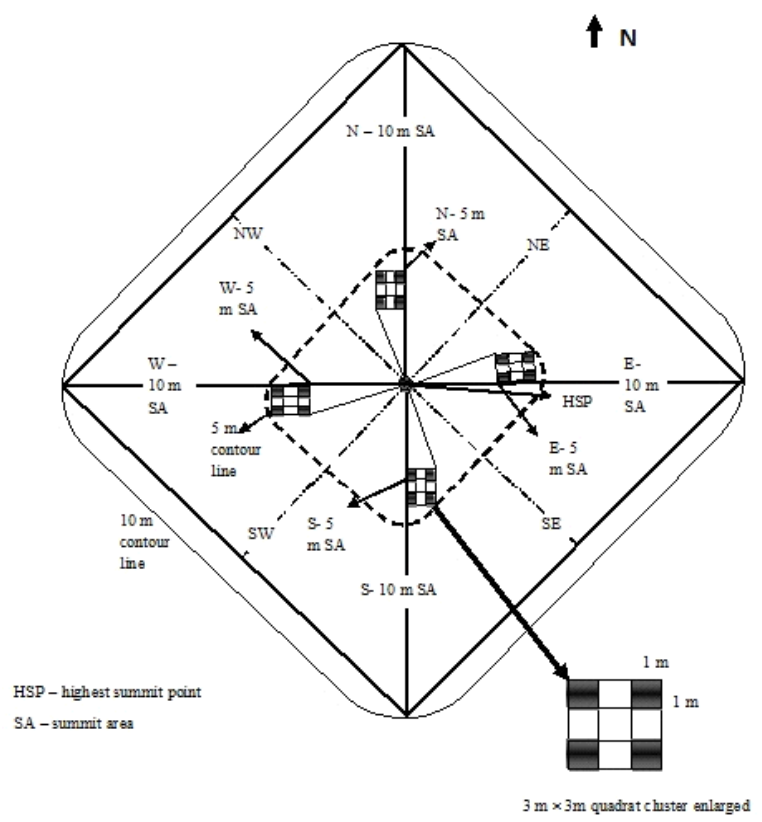

Figure 2. Sampling design (after Pauli et al. 2004).

top cover (\%) of surface types (vascular plant, lichen, bryophyte, scree, bare ground, and litter cover) were recorded based on visual observation. Each corner quadrat was divided into 100 cells of $0.1 \mathrm{~m} \mathrm{x} 0.1 \mathrm{~m}$ using a wooden grid frame for frequency count. Presence/ absence of vascular plant was recorded in each grid cell.

\section{PLANT LIFE FORM CLASSIFICATION}

Plant species were classified as one of the five principle life forms described by Raunkiaer (1934), viz. chamaephytes (CHP), cryptophytes (CRP), hemicryptophytes (HCP), phanerophytes (PHP) and therophytes (THP).

\section{DISTRIBUTION PATTERNS}

Elevation and biogeographic (chorotypic) patterns of distribution of plant species recorded in each summit was based on the updated version of Annotated Checklist of Flowering Plants of Nepal (Press et al. 2002) and Flora of China (Zheng-Yi and Raven 1996-2003) available online, and Flora of Mustang (Ohba et al. 2008). Based on the biogeographical range of distribution, the following categories were made: (i) Himalayan endemics $(H E)$ : those species which are endemic to the Himalaya (spreading over 5 countries-India, Nepal, Bhutan, China (Tibet) and Pakistan; the Himalaya are bordered on the north by the Tibetan Plateau, south by the IndoGangetic Plain, northwest by the Karakoram and Hindu Kush ranges, and east by the Indian state of Arunachal Pradesh); (ii) pan-Himalayan distribution (PE): species whose distribution crosses the boundary of Himalayan range, but restricted to the areas lying adjacent to the Himalaya (including Himalaya as above); and (iii) Broad range of distribution $(B E)$ : species having wider range of distribution crossing the territory of pan-Himalaya.

\section{DATA ANALYSIS}

Species richness ( $\alpha$-diversity) is the principle measure of diversity considered in this study. It was obtained at the level of $1 \mathrm{~m} \times 1 \mathrm{~m}$ quadrat and quadrat-cluster. Total number of species from all SAS and quadrats per summit is defined as $\gamma$-diversity (Whittaker 1972). The difference in mean species richness among summits was compared through one-way ANOVA. Two-way ANOVA was performed to see the effect of summit and aspect (at main compass directions) on species richness at quadrat level.

For each species recorded in the summits, lower and upper elevation distribution limits were obtained based on the empirical data and literature. The difference between these two limits gave the elevation amplitude or vertical range for each species. Plant species recorded in each summit were grouped into five categories of elevation distribution $(\leq 500,>500-1000,>1000-1500$, $>1500-2000$ and $>2000$ masl).

Indicator species analysis (ISA) was used to evaluate species associations with groups of sample units in a particular summit. This method produces indicator values for each species in a group ranging from 0 (no indication) to 100 (perfect indication), which were then tested for statistical significance using a Monte Carlo test (McCune \& Mefford 1999).

\section{POSSIBLE IMPACT OF CLIMATE CHANGE ON SPECIES DISTRIBUTION}

We followed global emission scenarios provided by IPCC to assess the possible impacts of global surface temperature rise on species distribution (Table 2). IPCC 
emission scenarios are grouped into four families (A1, A2, B1 and B2; Table 2) that explore alternative development pathways, covering a wide range of demographic, economic and technological driving forces and resulting green house gas (GHG) emissions (IPCC 2007).

Here we used B1 (lowest prediction) and A1F1 (highest prediction) scenarios for the projection of likely impacts on the species distribution. Using these IPCC emission scenarios, we calculated the range of elevation in which there is possible impact of increased temperature on species distribution based on local adiabatic lapse rate. The adiabatic lapse rate of temperature is the rate of decrease in air temperature with increasing elevation, which is used to explain the potential shift of vegetation in elevation gradient due to climate change (Van de Ven 2007; Medina et al. 2011). We have taken $0.53^{\circ} \mathrm{C}$ as the standard value for local adiabatic lapse rate per $100 \mathrm{~m}$ rise in elevation in Nepal Himalaya (Bhattarai et al. 2004). Those elevation ranges for individual species, which fall on the likely impact range of increased temperature, were grouped in different vulnerability categories. Species with lower elevation amplitude were treated as more vulnerable than those with higher amplitude.

\section{Results}

\section{SPECIES RICHNESS PATTERN}

Altogether, 176 species of vascular plant, belonging to 96 genera and 49 families, were recorded in the present
Table 2. Projected global surface warming at the end of 21st century (from IPCC 2007). Data shown are temperature change ( ${ }^{\circ} \mathrm{C}$ at 2090-2099).

\begin{tabular}{lcc}
\hline Case & Best estimate & Likely range \\
\hline $\begin{array}{l}\text { Constant year 2000 } \\
\text { concentrations }\end{array}$ & 0.6 & $0.3-0.9$ \\
B1 scenario & 1.8 & $1.1-2.9$ \\
A1T scenario & 2.4 & $1.4-3.8$ \\
B2 scenario & 2.4 & $1.4-3.8$ \\
A1B scenario & 2.8 & $1.7-4.4$ \\
A2 scenario & 3.4 & $2.0-5.4$ \\
A1F1 scenario & 4.0 & $2.4-6.4$ \\
\hline
\end{tabular}

study (Supplementary Material 1). Asteraceae with 28 genera was the largest family, and Potentilla (Rosaceae) with 10 species was the largest genus. The landscapelevel diversity ( $\gamma$-diversity, total 176 from all summits) decreased in summits representing different ecotones from lower to higher elevations (Table 3). Although the two lower-elevation summits of subalpine-lower alpine (SMA) and lower alpine-middle alpine (SMB) ecotones did not vary much in total species occurrence, a sharp decline in total number of species was observed from middle alpine-upper alpine (SMC) to upper alpinesubnival (SMD) ecotones (the two higher-elevation summits) (Table 3).

A similar trend was observed for richness of species at the level of quadrat-cluster (Table 3). One-way ANOVA and Tukey's range test showed that the value of species richness at the quadrat-cluster level was significantly higher in two lower-elevation summits than in the

Table 3. Species diversity measures at different spatial scales in summits along elevation gradient.

\begin{tabular}{|c|c|c|c|c|c|c|c|}
\hline \multirow{2}{*}{ Diversity measures } & \multicolumn{4}{|c|}{ Summits at different ecotones* } & \multirow[t]{2}{*}{ Overall } & \multirow[t]{2}{*}{$F$} & \multirow[t]{2}{*}{$P$} \\
\hline & SMA & SMB & SMC & SMD & & & \\
\hline $\begin{array}{l}\gamma \text {-diversity at summit } \\
\text { level }\end{array}$ & 103 & 102 & 65 & 41 & 176 & & \\
\hline $\begin{array}{l}\alpha \text {-diversity at } \\
\text { quadrat-cluster level }\end{array}$ & $32.25 \pm 3.30^{\mathrm{a}}$ & $26.75 \pm 1.31^{\mathrm{ab}}$ & $23.50 \pm 0.64^{\mathrm{b}}$ & $16.00 \pm 1.73^{\mathrm{c}}$ & $25.20 \pm 1.70$ & 13.37 & 0.01 \\
\hline $\begin{array}{l}\alpha \text {-diversity at } \\
\text { quadrat level }\end{array}$ & $14.19 \pm 1.03^{\mathrm{a}}$ & $13.94 \pm 0.94^{\mathrm{a}}$ & $15.19 \pm 0.48^{a}$ & $8.00 \pm 1.01^{\mathrm{b}}$ & $13.15 \pm 0.55$ & 12.06 & $<0.001$ \\
\hline
\end{tabular}

*SMA = subalpine-lower alpine (4150 m); SMB = lower alpine-middle alpine (4575 m), SMC = middle alpine-upper alpine (4835 m), SMD = upper alpine-subnival $(5005 \mathrm{~m})$. The different superscript letters in each category of diversity measures represent significant difference (at $\mathrm{p}<0.05$ level) based on one-way-ANOVA and Tukey’s range test. 
summits at higher elevations (Table 3). Contrary to these findings, species richness at the quadrat level did not reflect a sharp trend, except the value was significantly low for summit at highest elevation (SMD, Table 3). Tukey's range test showed that the three lower-elevation summits had almost similar value of species richness at quadrat level.

Two-way ANOVA clearly showed no consistent trend in species richness among summits for four compass directions (Table 4). However, the significant interaction term between aspect and summit indicated that the effect of aspect was different in different summits (Table 4). The two lower-elevation summits (SMA and SMB) comprised greater number of species at quadrat level on shady northern slopes, whereas the two high-elevation summits (SMC and SMD) showed greater number of species on exposed (generally western) slopes (data not shown).

\section{BIOGEOGRAPHICAL PATTERN OF DISTRIBUTION}

Biogeographical (chorotype) classification was only available for 170 species identified up to species level. The alpine-nival zone of the study area was dominated by Himalayan endemics (Table 5), which represented $58.3 \%$ of total species recorded in the four summits. The second largest group was species with panHimalayan distribution (28.8\%), followed by species with broad range of geographical distribution (12.9\%).

\section{ELEVATION PATTERN OF DISTRIBUTION}

The study area was dominated by species with broad elevation ranges (Figure 3). Among the total $(n=170)$, $34.1 \%$ species $(n=58)$ had an elevation range $>2000 \mathrm{~m}$, and $1.2 \%(n=2)$ had a range $<500 \mathrm{~m}$ (Figure 3$)$. In general,
Table 4. Two-way ANOVA showing the effect of summit and aspect (at main compass directions) on species richness at the quadrat level. Species richness values were log10 transformed before analysis.

\begin{tabular}{lccccc}
\hline Source & $\begin{array}{c}\text { Sum of } \\
\text { Square }\end{array}$ & df & $\begin{array}{c}\text { Mean } \\
\text { Square }\end{array}$ & F & P \\
\hline Intercept & 68.439 & 1 & 68.439 & 4345.090 & $<0.0001$ \\
Summit & 0.695 & 3 & 0.232 & 14.699 & $<0.0001$ \\
Aspect & 0.101 & 3 & 0.034 & 2.138 & 0.109 \\
Summit* & 0.424 & 8 & 0.053 & 3.361 & 0.004 \\
aspect & & & & & \\
Error & 0.709 & 45 & 0.016 & & \\
Total & 72.939 & 60 & & & \\
\hline
\end{tabular}

the lower-elevation summit (SMA) comprised greater proportions of species with a wide range of vertical distribution (species with lower temperate to alpine distribution with elevation range $>2000 \mathrm{~m}$ ), the proportion of which decreased with increasing elevations. The high-elevation summits (SMC and SMD) were generally represented by species with narrow elevation range $(<1500 \mathrm{~m})$. Higher proportions of Himalayan endemic species exhibited a narrow elevation range, followed by species with a pan-Himalayan distribution (Figure 4). Species with broad geographical distribution generally had a wide elevation amplitude (>2000 m) (Figure 4).

In the present study, 44 vascular plant species showed higher upper elevation limit ( $\geq 100 \mathrm{~m})$ than reported previously. The majority of such species were shrubs and forbs, like Artemisia subdigitata (previous record of $3000 \mathrm{~m}$ vs. $4575 \mathrm{~m}$ recorded in the present study), Cortia depressa (4900 vs. 5005 m), Epilobium brevifolium (4000 vs. $4575 \mathrm{~m}$ ), Heracleum sublineare (3850 vs. $4150 \mathrm{~m}$ ), Pleurospermum apiolens (4700 vs.

Table 5. Number of species (percentage in parentheses) classified under three biogeographical domains (chorotypes) in summits representing different ecotones along elevation gradient.

\begin{tabular}{|c|c|c|c|c|c|}
\hline \multirow[t]{2}{*}{ Chorotypes } & \multicolumn{4}{|c|}{ Summits at different ecotones* } & \multirow[t]{2}{*}{ Overall } \\
\hline & SMA & SMB & SMC & SMD & \\
\hline Himalayan endemic (HE) & $57(56.4)$ & $58(58.0)$ & $35(54.7)$ & $24(58.5)$ & $99(58.3)$ \\
\hline pan-Himalayan (PH) & $28(27.7)$ & $30(30.0)$ & $19(29.7)$ & $11(26.8)$ & $49(28.8)$ \\
\hline Broad range of distribution (BR) & $16(15.7)$ & $12(12.0)$ & $10(15.6)$ & $6(14.7)$ & $22(12.9)$ \\
\hline
\end{tabular}

*description of summits at different ecotones is given in Table $1 \& 3$. 

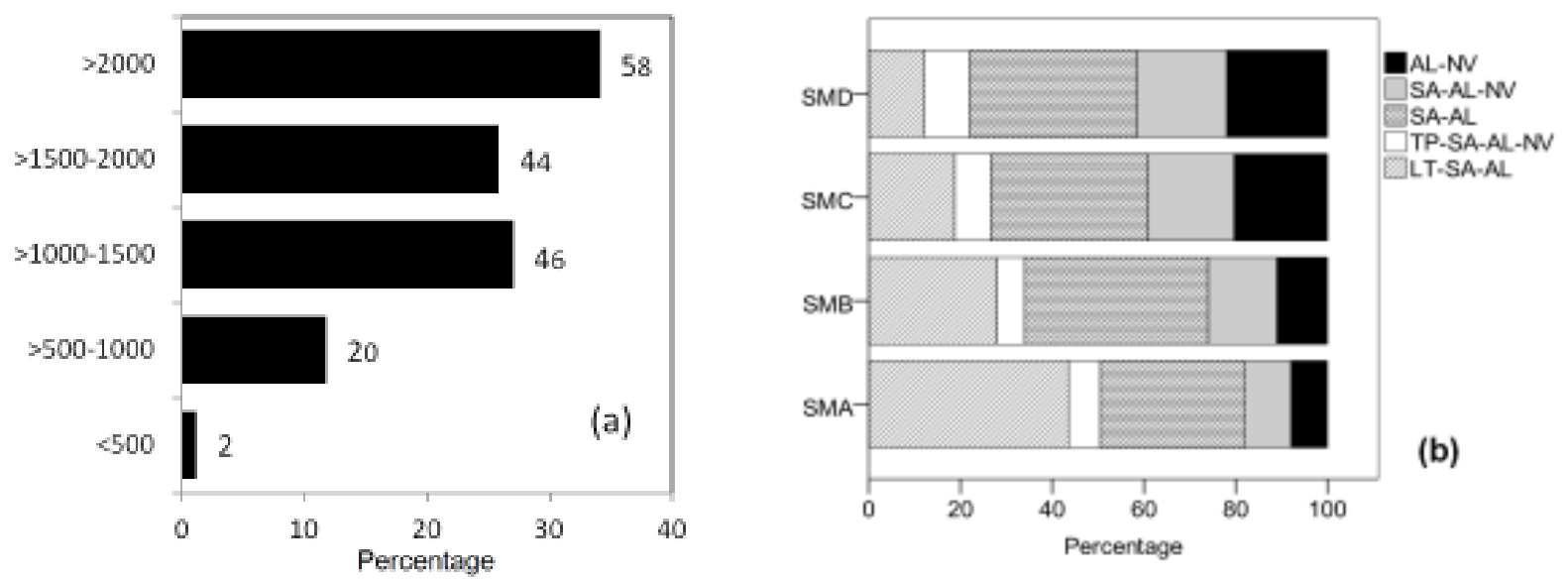

Figure 3. Elevation range of species: (a) elevation range for all species calculated as the difference between lower and upper elevation limits, (b) elevation range for species in four summits studied. In (a) value on the top of the bar represents number of species in each elevation range. Abbreviations in (b): Al-NV = alpine-nival; SA-AL-NV = subalpine-alpine-nival; SA-AL = subalpine-alpine; TP-SA-AL-NV = temperate-subalpine-alpine-nival; LT-SA-AL = lower temperate-subalpine-alpine.

$5005 \mathrm{~m}$ ), Potentilla exigua (4500 vs. 5005 m), Salix calyculata (4500 vs. $4835 \mathrm{~m}$ ) and Sedum ewersii (4500 vs. 5005 m). Among graminoids Agrostis pilosula (4600 vs. $4838 \mathrm{~m}$ ), Bromus himalaicus (3700 vs. $4150 \mathrm{~m}$ ), Elymus nutans (4600 vs. 5005 m), Festuca polycolea (4600 vs. $5005 \mathrm{~m}$ ), Роа аппиа (3500 vs. $4150 \mathrm{~m}$ ) and Kobresia williamsii (4000 vs. $4835 \mathrm{~m}$ ) also showed increased upper elevation limit than reported previously.

\section{INDICATOR SPECIES TO THE MOUNTAIN SUMMITS}

The indicator species analysis revealed that the species indicator to the study summits were mostly herbaceous taxa with biogeographical distribution restricted to the Himalayan region (50\% of total indicator species), followed by species with pan-Himalayan distribution (33\%). Only $17 \%$ of taxa identified as indicators were broad range species. Himalayan endemics and panHimalayan range species identified as indicators had almost equal share in all the study summits, except SMB where large proportion of indicators were those having broad distribution range (Figure 5a).

Majority of indicators (54\%) were chamaephytes, followed by hemicryptophytes (31\%), phenerophytes (8\%) and cryptophytes (6\%). But, majority of indicators at higher elevations were hemicryptophytes and that of lower elevations were chamaephytes (Figure 5b).

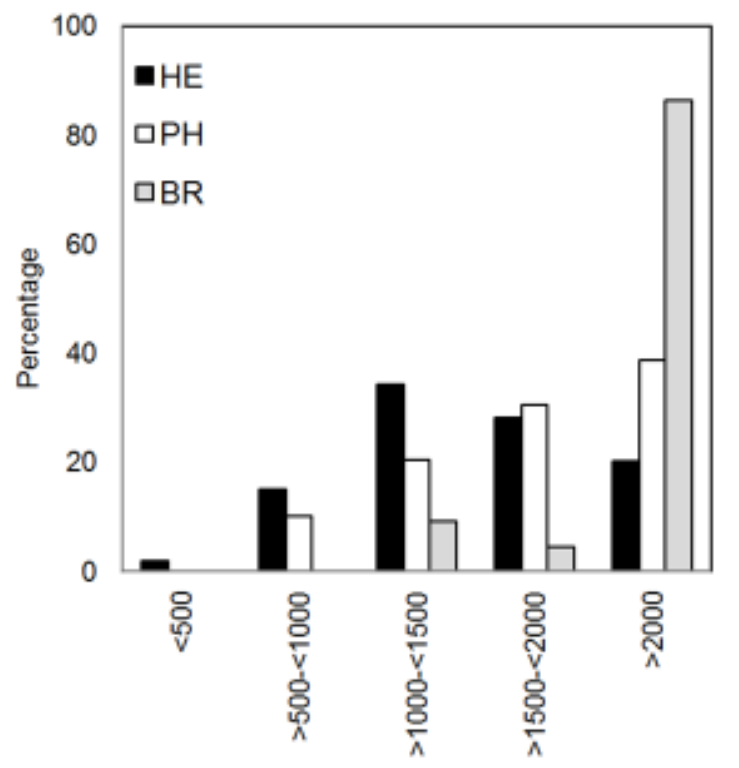

Figure 4. Elevation range of species categorized into different chorotypes (HE-Himalayan endemic, PH-pan-Himalayan, BR-broad geographical distribution).

\section{POSSIBLE IMPACTS OF CLIMATE CHANGE ON SPECIES DISTRIBUTION}

The analysis revealed that, under different emission scenarios (low, intermediate and high), 40 plant species were identified as vulnerable and expected to adapt through range shift to compensate for warming or develop specific traits for adaptation on the current 

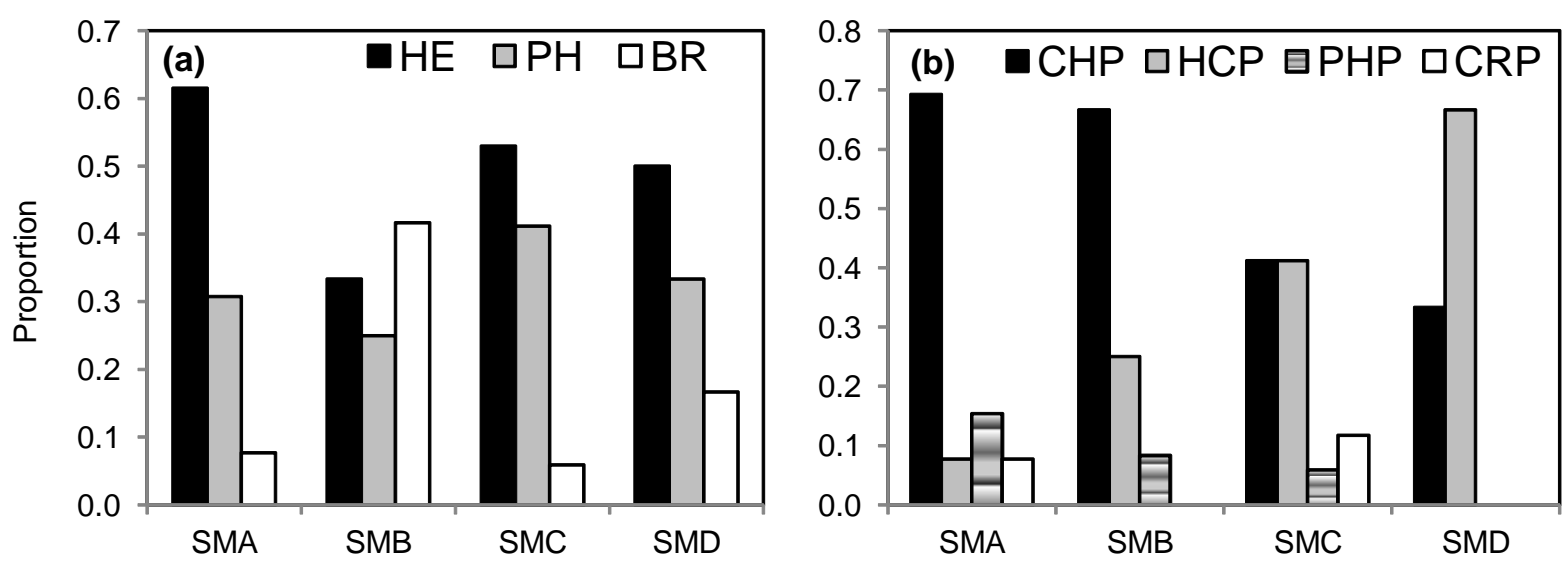

Figure 5. Proportion of indicator species in different summits according to (a) chorotype (HE-Himalayan endemic, PH-panHimalayan, BR-broad geographical distribution), and (b) life form categories (CHP-chamaephytes, CRP-cryptophytes, HCP-hemicryptophytes, PHP-phanerophytes, and THP-therophytes). Description of summits is given in Table 1.

habitat (Table 6, 7). The predicted vulnerable plant species belonged to 17 vascular plant families. Most of them $(n=8)$ belonged to Asteraceae, followed by Gentianaceae $(n=5)$, Apiaceae $(n=4)$, Crassulaceae ( $n$ $=3)$ and Rosaceae $(n=3)$ (Table 7).

Of the 170 species analyzed, $1.76 \%(n=3)$ were regarded as most vulnerable, as they fall on the likely impact range within $\mathrm{B} 1$ scenario (the lowest emission prediction made by IPCC) (Table 6, 7). They were all chamaephytes and Himalaya endemics. Similarly, 22.94\% species ( $n=39$ ) having their elevation range within the likely impact range for A1F1 scenario (the highest emission prediction made by IPCC), were treated as vulnerable (Table 6,7$)$. Out of which $1.18 \%$ species ( $n=$ 2) were found to be highly vulnerable (vulnerability rank I), $6.47 \%$ species $(n=11)$ moderately vulnerable (vulnerability rank II), and $15.29 \%$ species $(n=26)$ less vulnerable (vulnerability rank III) (Table 7). Among the vulnerable species, $56.41 \%$ species $(n=22)$ were chamaephytes and $28.20 \%$ species $(n=11)$ were hemicryptophytes. Cryptophytes and Phanerophytes each comprised $7.69 \%$ species $(n=3)$ (Table 7). Similarly, $79.49 \%$ species $(n=31)$ were Himalaya endemics and $20.51 \%$ species $(n=8)$ were having pan-Himalayan distribution (Table 7).
Table 6. Predicted impact of climate change on different altitudinal ranges.

\begin{tabular}{lllll}
\hline $\begin{array}{l}\text { Emission } \\
\text { scenario }\end{array}$ & $\begin{array}{l}\text { Rate of average } \\
\text { warming }\left({ }^{\circ} \mathrm{C}\right)\end{array}$ & $\begin{array}{l}\text { Likely } \\
\text { impacted } \\
\text { elevation } \\
\text { range (m) }\end{array}$ & $\begin{array}{l}\text { Number } \\
\text { of } \\
\text { species }\end{array}$ \\
\hline $\mathrm{B} 1^{1}$ & Low & 1.1 & 208 & 1 \\
& Intermediate & 2.0 & 378 & 0 \\
& High & 2.9 & 548 & 2 \\
$\mathrm{~A} 1 \mathrm{~F} 1^{2}$ & Low & 2.4 & 453 & 2 \\
& Intermediate & 4.4 & 830 & 11 \\
& High & 6.4 & 1208 & 26 \\
\hline
\end{tabular}

${ }^{1}$ IPCC emission scenario describing a world of very rapid economic growth, a global population that peaks in mid century and rapid introduction of new and efficient technologies (IPCC 2007). ${ }^{2}$ IPCC emission scenario describing a fossil intensive world with the population same as in B1 scenario (IPCC 2007). ${ }^{3}$ Predicted average surface warming scenario given by IPCC 2007.

\section{Discussion}

A general trend of decreasing vascular plant species richness along the subalpine-nival gradient at different scales of measurement is observed in the present study. A similar trend in species richness has been reported 
Table 7. Plant species having altitudinal amplitude within the likely impact range of projected average global surface warming.

\begin{tabular}{|c|c|c|c|c|}
\hline Name of plant species & Family & Chorotype $^{2}$ & Altitudinal amplitude $(\mathrm{m})$ & $\begin{array}{l}\text { Vulnerability } \\
\text { rank }^{3}\end{array}$ \\
\hline \multicolumn{5}{|l|}{ B1 scenario } \\
\hline Taraxacum pseudostenoceras & Asteraceae & $\mathrm{HE}$ & 175 & I \\
\hline Bupleurum himalayense & Apiaceae & $\mathrm{HE}$ & 400 & III \\
\hline Heracleum sublineare & Apiaceae & $\mathrm{HE}$ & 550 & III \\
\hline \multicolumn{5}{|l|}{ A1F1 scenario } \\
\hline Taraxacum pseudostenoceras & Asteraceae & $\mathrm{HE}$ & 175 & I \\
\hline Bupleurum himalayense & Apiaceae & $\mathrm{HE}$ & 400 & I \\
\hline Heracleum sublineare & Apiaceae & $\mathrm{HE}$ & 550 & II \\
\hline Potentilla caliginosa & Rosaceae & HE & 600 & II \\
\hline Astragalus oplites & Fabaceae & $\mathrm{PH}$ & 650 & II \\
\hline Bromus himalaicus & Poaceae & $\mathrm{HE}$ & 650 & II \\
\hline Haplosphaera himalayensis & Apiaceae & $\mathrm{HE}$ & 675 & II \\
\hline Gentinella stellariifolia & Gentianaceae & $\mathrm{HE}$ & 735 & II \\
\hline Aconitum naviculare var. leiocarpum & Ranunculaceae & $\mathrm{HE}$ & 790 & II \\
\hline Gentiana algida var. przewalskii & Gentianaceae & $\mathrm{HE}$ & 800 & II \\
\hline Rhodiola crenulata & Crassulaceae & $\mathrm{PH}$ & 800 & II \\
\hline Saussurea leontodontoides & Asteraceae & $\mathrm{PH}$ & 800 & II \\
\hline Stellaria congestiflora & Caryophyllaceae & $\mathrm{HE}$ & 805 & II \\
\hline Anaphalis cavei & Asteraceae & $\mathrm{HE}$ & 900 & III \\
\hline Swertia multicaulis & Gentianaceae & $\mathrm{HE}$ & 900 & III \\
\hline Gentiana himalayensis & Gentianaceae & $\mathrm{HE}$ & 900 & III \\
\hline Polygonatum cirrhifolium & Liliaceae & $\mathrm{PH}$ & 900 & III \\
\hline Potentilla forrestii & Rosaceae & HE & 905 & III \\
\hline Veronica cephaloides & Scrophulariaceae & $\mathrm{HE}$ & 975 & III \\
\hline Pedicularis cheilanthifolia & Orobanchaceae & $\mathrm{PH}$ & 1000 & III \\
\hline Silene nigrescens & Caryophyllaceae & HE & 1005 & III \\
\hline Saussurea polystichoides & Asteraceae & $\mathrm{HE}$ & 1005 & III \\
\hline Lonicera obovata & Caprifoliaceae & $\mathrm{HE}$ & 1075 & III \\
\hline Astragalus himalayanus & Fabaceae & $\mathrm{HE}$ & 1075 & III \\
\hline Sedum gagei & Crassulaceae & HE & 1100 & III \\
\hline Swertia cuneata & Gentianaceae & $\mathrm{HE}$ & 1100 & III \\
\hline Kobresia uncinoides & Cyperaceae & $\mathrm{HE}$ & 1100 & III \\
\hline Pleurospermum album & Apiaceae & $\mathrm{HE}$ & 1105 & III \\
\hline Rhodiola hemalensis & Crassulaceae & $\mathrm{PH}$ & 1135 & III \\
\hline Polygonum tubulosum & Liliaceae & $\mathrm{HE}$ & 1150 & III \\
\hline Cicerbita macrorhiza var. saxatilis & Asteraceae & $\mathrm{HE}$ & 1200 & III \\
\hline Thalictrum alpinum var. minutissimum & Ranunculaceae & HE & 1200 & III \\
\hline Lonicera minutifolia & Caprifoliaceae & $\mathrm{HE}$ & 1200 & III \\
\hline Soroseris hookeriana & Asteraceae & $\mathrm{PH}$ & 1200 & III \\
\hline Rhododendron nivale & Ericaceae & PH & 1200 & III \\
\hline Cremanthodium purpureifolium & Asteraceae & HE & 1205 & III \\
\hline Potentilla exigua & Rosaceae & $\mathrm{HE}$ & 1205 & III \\
\hline Primula capitata & Primulaceae & $\mathrm{HE}$ & 1205 & III \\
\hline Salix lindleyana & Salicaceae & $\mathrm{HE}$ & 1205 & III \\
\hline
\end{tabular}

${ }^{2} \mathrm{HE}=$ Himalaya endemic, $\mathrm{PH}=$ Pan Himalayan distribution, $\mathrm{BR}=$ Broad range of distribution.

${ }^{3} \mathrm{I}$ = highly vulnerable, $\mathrm{II}=$ moderately vulnerable, III = less vulnerable. 
along an alpine to nival gradient in the Swiss Alps (Erschbamer et al. 2010; Vittoz et al. 2010). A linear decrease in species richness after reaching its peak at mid elevations has also been shown by previous studies conducted in the Himalaya and other mountain ranges (Grytness and Vetaas 2002; Carpenter 2005; Ghimire et al. 2006; Bruun et al. 2006). Both broad- and local-scale environmental factors have contributions on species richness and distribution patterns along an elevation gradient. Elevation itself represents a complex combination of numerous other environmental variables, including temperature, precipitation, potential evapo-transpiration, and edaphic factors including soil texture and substrate stability (Klîmes 2003).

On the broader scale, there are many hypotheses on decreasing species richness at higher elevation, for example, water energy dynamics (O’Brien 1998), species area relationship and ecotone effect (Rahbek 1995; Lomolino 2001), and mid-domain effect (Grytnes and Vetaas 2002). The species-area relationship hypothesis expects the number of species to increase with an increase in area (Rahbek 1995; Lomolino 2001). Generally, available area along the subalpine-nival gradient decreases linearly with increasing elevations. Species composition in different summits along the subalpine to nival gradient may have been affected differently by this decline in area because the later is directly related to the species pool of surrounding mountain land mass. In the upper part of the elevation gradient, decreased land area surrounding the mountain summits greatly affects the existing species pool, which is further constrained by mountain barrier limiting potential immigrants to enter into the summit (cf. Lomolino 2001).

At the local-scale, the observed trend of decreasing species richness with increasing elevation along the alpine-nival gradient signifies the important role of elevation, aspect, radiation and substrate types to shape species richness and distribution patterns. The decreasing species richness towards high-elevation can be attributed to a number of micro- and meso-scale environmental factors affecting the mountain summits. Most importantly, it can be attributed to lower moisture content and relatively lower temperature (low energy) at higher elevations (O’Brien 1998), reduced growing season, ecophysiological constraints, deep snow cover and intense solar radiation (Körner 2000).

While the proportions of Himalayan endemics and species with pan-Himalayan distribution were higher at the high-elevation summits of the study area, they generally had narrow elevation ranges. In contrast, the proportion of species with broad geographic distributions and a wide elevation range was higher at lower elevation summits. These results signify that the distribution of species with a wide elevation range is restricted to lower-elevation summits, while narrow range species are concentrated on upper-elevation summits. A similar trend has been documented on other alpine areas of the globe, e.g., in Sierra de Cartagena, southeastern Spain (Ferrer-castán and Vetaas 2003) and in Swiss inner Alps (Vittoz et al. 2010). The comparatively lower elevation amplitudes of Himalayan endemics signify their narrow range size and habitat specificity (Ferrer-castán and Vetaas 2003). Such range restricted species are more vulnerable to rapid climate change (Salick et al. 2009). Most of the climate change studies on high elevation zones of the globe have shown the loss of diversity and extinction path of endemic species because these may be outcompeted by faster growing, more aggressive lower elevation species extending their range to higher elevations and/or their loss due to increased pressure for limited resources (Salick et al. 2014; Erschbamer et al. 2010).

Different summits under investigation showed different indicator species in the present study. A complete turnover of indicator species along the sampled elevation gradient is an indication of distinct phytoclimates (Grau et al. 2012). Indicator species analysis further indicates the importance of endemic species in shaping the alpine-nival vegetation of the study area as most of the indicators of local vegetation were Himalayan endemics. This pattern of species indicators to mountain summits representing broader Himalayan gradients (also including present study site) was also reported (Salick et al. 2014). Warming Himalayan temperatures and concurrent changes in precipitation (IPCC 2007) have increased the pressure for the upward migration of habitat specific alpine species. Opportunistic, lower elevational species with broader amplitudes may push 
the high elevation Himalayan endemic species with more compressed elevational amplitudes towards upward migration (Telwala et al. 2013). At a time when there is absence of suitable habitat reaching up to the permanent snow line (around $5000 \mathrm{~m}$ ), these species are left nowhere to go and thus are of great concern in conservation.

According to IPCC, the Himalaya will experience predicted temperature rise of $5-6^{\circ} \mathrm{C}$ and precipitation increase by $20-30 \%$ at the end of $21^{\text {st }}$ century (IPCC 2007), which is higher than the global average $\left(0.6-4.0^{\circ} \mathrm{C}\right)$. Thus species ranges, which depend on temperature and precipitation, are expected to change considerably (Salick et al. 2009; Salick et al. 2014). The historical temperature trend for the Himalayan region strongly supports this view. For example, annual warming of $0.06^{\circ} \mathrm{C}$ (Shrestha et al. 1999) has been reported for Nepal Himalaya. Similarly, according to Sing and Smith (2009), the average temperature in Nepal is rising by an average of $0.41^{\circ} \mathrm{C}$ per decade. Talking about Indian subcontinent as a whole, an annual mean surface air temperature is projected to rise by 1.7 to $2.0^{\circ} \mathrm{C}$ during 2030s (Singh et al. 2011). These projections are quite similar to the projections made by IPCC, i.e. a higher warming trend than global average.

Although this study is limited by the lack of longterm data for predicting potential impact of climate change in real sense, the analysis of current distribution patterns and examination of the biological traits of taxa of the alpine-nival ecosystem provides baseline evidence from which we can make predictions for future distribution patterns influenced by climate change. Our estimates suggest that under an expected $1.1^{0}-6.4^{\circ} \mathrm{C}$ rise on surface temperature by the end of $21^{\text {st }}$ century (IPCC 2007; A1F1 \& B1 emission scenario), 22.94\% of species documented in this study exist within an elevational range that is within the likely impact range of projected global temperature rise and are expected to be highly vulnerable to extinction. Such species must adapt to the existing climate by upslope migration to compensate with increased temperature. Most of such species are Himalayan endemics, followed by species with panHimalayan distribution. The comparatively narrow elevational amplitude of Himalaya endemics is the main cause making them more vulnerable to future climate change.

In the present study, 44 species (26\%) of vascular plant showed increased upper elevation limit ( $\geq 100 \mathrm{~m})$ than reported previously. Although the difference in upper elevation limit of vascular plants may reflect the lack of proper scientific documentation in the past, the possibilities of upward shift of species due to earlier climate change events cannot be ruled out. There will be a possibility for invasion of unpalatable weed species in the alpine-nival ecosystem in response to warming. However, a thorough study is needed to overcome the misleading inference related to insufficiency of collection/documentation and climate change impact.

\section{Acknowledgements}

Funding for this research was provided by National Geographic Society, USA. We acknowledge Department of National Park and Wildlife Conservation Nepal and National Trust for Nature Conservation for issuing permits for this research.

\section{References}

Bhattarai K.R., Vetaas O.R. and Grytnes J.A. 2004. Fern species richness along a central Himalayan elevational gradient, Nepal. Journal of Biogeography, 31: 389-400.

Bruun H.H., Jon M., Risto V., Grytnes J.A., Lauri O. and Anders A. 2006. Effect of altitude and topography on species richness of vascular plants, bryophytes and lichens in alpine communities. Journal of Vegetation Science, 17: 37-46.

Carpenter C. 2005. The environmental control of plant species density on a Himalayan elevation gradient. Journal of Biogeography, 32: 999-1018.

Conservation International. 2012. Biological diversity in the Himalaya. In: Encyclopedia of Earth. (Cutler J. Cleveland, ed.). [Online] URL: <http://www.eoearth.org/article/ Biological_diversity_in_the_Himalaya $>$ (retrieved on May 20, 2013).

Erschbamer B., Mallaun M., Unterluggauer P., Abdaladze O., Akhaltasi M. and Nakhutsrishvili G. 2010. Plant diversity along altitudinal gradient in the Central Alps (South Tyrol, Italy) and in the Central Greater Caucasus (Kazbegi region, Georgia). Tuexenia, 30: 11-29.

Ferrer-castán D. and Vetaas O.R. 2003. Floristic variation, chorological types and diversity: do they correspond at broad and local scales? Diversity and Distributions, 9: 221-235. 
Ghimire S.K., Mickey D. and Aumeeruddy-Thomas Y. 2006. Himalayan medicinal plant diversity in an ecologically complex high altitude anthropogenic landscape, Dolpo, Nepal. Environmental Conservation, 33: 128-140.

Ghimire S.K. 2005. The endemic flora in Dolpo, North-West Nepal: distribution patterns, life forms, habitat specificity and conservation status. Botanica Orientalis, 5: 30-39.

Grabherr G., Gottfried M. and Pauli H. 2001. Long-term monitoring of mountain peaks in the Alps. In: Biomonitoring: General and Applied Aspects on Regional and Global Scales (C.A. Burga and A. Kratochwil, eds.), pp. 153-177. Kluwer, Dordrecht.

Grau O., Ninit J.M., Ferre A., Font X. and Grytnes J.A. 2012. Altitudinal species richness patterns of vascular plants in the south-eastern Pyrenees and nearby mountains of Catalonia. Plant Ecology and Diversity, 5: 115-126.

Grytnes J.A and Vetaas O.R. 2002. Species richness and altitude: a comparison between null models and interpolated plant species richness along the Himalayan altitude gradient, Nepal. The American Naturalist, 159: 294-304.

IPCC. 2007. Climate Change 2007: Impacts, adaptation and vulnerability. In: Contribution of Working Group II to the Fourth Assessment Report of the Intergovernmental Panel on Climate Change (M.L. Parry, O.F. Canziani, J.P. Palutikof, P.J. van der Linden and C.E. Hanson, eds.). Cambridge University Press, Cambridge, United Kingdom and New York, NY, USA.

Jonas T., Rixen C., Sturm M. and Stoeckli V. 2008. How alpine plant growth is linked to snow cover and climate variability. Journal of Geophysical Research, 113: G03013. [online] URL: http://onlinelibrary.wiley.com/doi/10.1029/ 2007JG000680.

Klîmes L. 2003. Life forms and clonality of vascular plants along an altitudinal gradient in E Ladakh (NW Himalayas). Basic and Applied Ecology, 4: 317-328.

Körner C. 2000. Why are there global gradients in species richness? Mountains might hold the answer. Tree, 15: 513514.

Körner C. 2003. Alpine Plant Life: Functional Plant Ecology of High Mountain Ecosystems. Springer, USA.

Lomolino M.V. 2001. Elevation gradients of species-density: historical and prospective views. Global Ecology and Biogeography, 10: 3-13.

Mani M.S. 1978. Ecology and Phytogeography of High Altitude Plants of the Northwest Himalaya: Introduction to High Altitude Botany. Oxford and IBH Publishing Company, New Delhi, India.

McCune B. 2007. Improved estimates of incident radiation and heat load using non-parametric regression against topographic variables. Journal of Vegetation Science, 18: 751-775.

McCune B. and Mefford M. J. 1999. Multivariate Analysis of Ecological Data, PC-ORD Version 4.25. MjM Software, Gleneden Beach, Oregon, USA.

Medina F.G., Terborgh J., Socolar S.J. and Pimm S.L. 2011. Elevation ranges of birds on a tropical montane gradient lag behind warming temperature. PLOS ONE, 6 (12): e28535. [online] URL: http://www.plosone.org/article/ info\%3Adoi\%2F10.1371\% 2Fjournal.pone.0028535.
Nagy L. and Grabherr G. 2009. The Biology of Alpine Habitats. Oxford University Press, Oxford, UK.

O’Brien E.M. 1998. Water-energy dynamics, climate and prediction of woody plant species richness, an interim general model. Journal of Biogeography, 25: 379-398.

Ohba H., Iokawa T. and Sharma L.R., eds. 2008. Flora of Mustang, Nepal. Kodansha Scientific Ltd, Tokyo, Japan.

Pauli H., Gottfried M., Hohenwallner D., Reiter K., Casale R. and Grabherr G., eds. 2004. GLORIA Field Manual: MultiSummit Approach. Global Observation Research Initiative in Alpine Environments. European Communities, Luxemburgh, Belgium.

Press J.R., Shrestha K.K. and Sutton D.A. 2002. Annotated Checklist of the Flowering Plants of Nepal. The Natural History Museum, London, UK.

Rahbek C. 1995. The elevational gradient of species richness: a uniform pattern. Ecography, 18: 200-205.

Rajbhandari K.R. and Adhikari M.K. 2009. Endemic Flowering Plants of Nepal Part 1. Department of Plant Resources Bulletin, Special Publication No. 1. Department of Plant Resources, Government of Nepal, Kathmandu, Nepal.

Raunkiaer C. 1934. The Life Forms of Plants and Statistical Plant Geography. The Clarendon Press, Oxford.

Salick J. and Byg A. 2007. Indigenous Peoples and Climate Change. A Tyndall Centre Publication, Tyndall Centre for Climate Change Research, Oxford.

Salick J., Zhendong F. and Byg A. 2009. Eastern Himalayan alpine plant ecology, Tibetan ethnobotany, and climate change. Global Environmental Change, 19: 147-155.

Salick J., Ghimire S.K., Fang, Z.D., Dema S. and Konchar K.M. 2014. Himalayan alpine vegetation, climate change and mitigation. Journal of Ethnobiology, 34(3): 276-293.

Shrestha T.B. and Joshi R.M. 1996. Rare, Endemic and Endangered Plants of Nepal. WWF Nepal Program, Kathmandu, Nepal.

Shrestha A.B., Wake C.P., Mayewski P.A. and Dibb J.E. 1999. Maximum temperature trends in the Himalaya and its vicinity: an analysis based on temperature records from Nepal for the period 1971-94. Journal of Climate, 12: 2775-2787.

Singh B. and Smith P. 2009. An Assessment of Climate Change, Forests and Biodiversity in Nepal. USAID, Nepal.

Singh S.P., Bassignana-Khadka I., Karky B.S. and Sharma E. 2011. Climate Change in the Hindu Kush Himalayas: The State of Current Knowledge. International Centre for Integrated Mountain Development, Kathmandu, Nepal.

Telwala Y., Brook B.W., Manish K. and Pandit M.K. 2013. Climate-induced elevational range shifts and increase in plant species richness in a Himalayan biodiversity epicenter. PLoS ONE, 8(2): e57103. [online] URL: http://www.plosone.org/ article/ info\%3Adoi\%2F10.1371\%2Fjournal.pone.0057103.

Tribsch A. and Schönswetter P. 2003. Patterns of endemism and comparative phylogeography confirm palaeoenvironmental evidence for Pleistocene refugia in the Eastern Alps. Taxon, 52: 477-497.

Van de Ven C. 2007. Plant species distribution under present conditions and forecasted for warmer climates in an arid mountain range. Earth Interactions, 11: 1-33. 
Vetaas O.R. and Grytnes J.A. 2002. Distribution of vascular plant species richness and endemic richness along the Himalayan elevation gradient in Nepal. Global Ecology and Biogeography, 11: 291-301.

Vittoz P., Camenisch M., Mayor R., Miserere L., Vust M. and Theurillat J.P. 2010. Subalpine-nival gradient of species richness for vascular plants, bryophytes and lichens in the Swiss Inner Alps. Botanic Helvetica, 120: 139-149.
Whittaker R.H. 1972. Evolution and measurement of species diversity. Taxon, 21: 213-251.

Yoshida T. 2006. Geobotany of the Himalaya (Part 1). Newsletter of Himalayan Botany, 37: 1-24.

Zhengyi W. and Raven P.H. 1996-2003. Flora of China. Science Press (Beijing), China and Missouri Botanical Garden Press (St. Louis), USA. 